OPEN ACCESS

Edited by:

Stephen Sterling,

University of Plymouth,

United Kingdom

Reviewed by:

Joy Kcenia Polanco-O'Neil, University of Wisconsin-Stevens

Point, United States

Alfonso Fernández Herrería,

University of Granada, Spain

*Correspondence:

Susanne C. Moser

promundi@susannemoser.com

Specialty section

This article was submitted to

Sustainable Organizations,

a section of the journal

Frontiers in Sustainability

Received: 01 February 2021

Accepted: 07 April 2021

Published: 30 April 2021

Citation:

Moser SC and Fazey I (2021) If It Is Life We Want: A Prayer for the Future (of the) University.

Front. Sustain. 2:662657.

doi: 10.3389/frsus.2021.662657

\section{If It Is Life We Want: A Prayer for the Future (of the) University}

\author{
Susanne C. Moser ${ }^{1,2,3 *}$ and loan Fazey ${ }^{4}$ \\ ${ }^{1}$ Susanne Moser Research \& Consulting, Hadley, MA, United States, ${ }^{2}$ Department of Landscape Architecture and Regional \\ Planning, University of Massachusetts-Amherst, Amherst, MA, United States, ${ }^{3}$ Environmental Studies Department, Antioch \\ University New England, Keene, NH, United States, ${ }^{4}$ Department of Environment \& Geography, University of York, York, \\ United Kingdom
}

Universities are one potentially important place - albeit not the only one - to initiate the next generation into becoming the adult humans needed to navigate the difficult future of the Anthropocene. The University of the future will fail this mission, if it only prepared young people in the technical expertise required to manage accelerating climate crises and the breakdown of Earth's life support and interlocking human systems. The depth and extent of transformation that awaits society requires people skilled in coping emotionally and in effectively engaging the plethora of challenges ahead with agility, creativity, resolve, vision, and integrity. It requires universities themselves to transform into institutions of human development that cease to participate, pardon and propagate patterns of exploitation and, instead, become singularly dedicated to restoring and regenerating the conditions for life. This paper articulates a vision of a radically different future "University." Building on others' calls for transformation-supporting education, we frame universities' role in the larger arc of inner and outer human and societal development. We spell out some of the implications and needs such a shift would entail. The paper is written in the spirit of the future University that we envision: not just from our analytical thinking brain, but drawing also on our imaginative/intuitive, emotional, and sensing/embodied ways of knowing. As such, it breaks with conventional academic writing and opens up wider possibilities for and commitment to life-affirming and restorative action.

Keywords: climate crisis, sustainability, Anthropocene, higher education, transformation, emancipation, initiation, human development

\section{PRAYER AS INTRODUCTION}

\author{
"Prayer is the absolute relation of the human heart to itself, to its own nature... \\ Prayer is ... a dialogue of man with himself, with his heart." \\ (Feuerbach, 1893, p. 123) \\ Future, Earth, Life - \\ You, promise of our days. \\ You, ground of our existence. \\ You, source of our being.
}


We come to you broken.

Maybe not broken, merely unfinished ${ }^{1}$.

And yet, with broken hearts:

We nearly broke you.

Today we come with our heads down, not with weapons of analysis, not with litanies of defenses, not with litanies of past achievements and arguments of why we deserve another chance, not even promises of how we will redeem ourselves. Today we come in prayer. We come to speak to our higher selves. We come to seek a higher education.

We know, we have disregarded you, Future; we have destroyed so much of you, Earth; we have dismissed you, Life - even as we depended, and still depend - on you. We have robbed you, overheated you, mined and undermined you. We have done so in plain sight and full knowing, even as you - generously gave us another day, another year; even as you spoiled us with riches, with beauty; even as you granted us shelter, water, food, companionship beyond our wildest dreams.

We deluded ourselves in thinking we were superior and independent, not embedded and elemental. We misunderstood our powers - thinking ourselves omnipotent and invincible, rather than formidable enough to make ourselves vulnerable to existential risk. We have made ourselves smart, but not yet wise; we do not yet know nor live up to our true name.

We have taught our young but not prepared them for the world we have created. We have educated them for a tomorrow that may never come, rather than ready them for the tomorrow that awaits. This, we now realize, leaves us all in danger, endangered.

Thus, we come to this precipice, hardly admitting that we ourselves created our own crises, barely recognizing them as the necessary end of the road, of our institutions, of our thinking, of the house of cards we ourselves have built. We come with all our broken promises, our failed prowess, humbly now, realizing how bereft we are, how much in need of change.

Here - Future, Earth, Life - we offer our brokenness, our hearts, our unfinished selves. We come to you to learn what we must learn.

For it is life we want. Another day. A role and task on Earth worthy of our name.

May it be so.

\section{A UNIVERSITY UNFIT FOR THE ANTHROPOCENE}

\section{The Complicit University}

Higher education can be - and has been - critically examined and, indeed, sharply criticized, for its contributions to unsustainability and for its possible role in a transition to sustainability. This critique has come from within and without. Some have pointed fingers at its financial entanglements with extractive, polluting, and exploitative industries that make it

\footnotetext{
${ }^{1}$ Gorman, A. (2021). The Hill We Climb. Poem read at the inauguration of President J.R. Biden, 46th President of the United States of America, January 20, 2021. https://news.harvard.edu/gazette/story/2021/01/amanda-gormansinauguration-poem-the-hill-we-climb/ [accessed January 29, 2021].
}

complicit with unsustainable, neoliberal forces rather than an instrument of good (Lave et al., 2010; Berman, 2014; Burke and Nik, 2014) $)^{2}$. Related to that, many have bemoaned its own carbon and ecological footprint (Mayo, 2019; Yañez et al., 2020). Others have focused on its outdated and hierarchical governance and slow responsiveness to an increasingly urgent sustainability crisis (Moon Christopher et al., 2018; O’Riordan et al., 2020). This has led to (self-)critical looks at institutional barriers to doing relevant research (Leal Filho et al., 2018) and to questions about pedagogy and whether or not it is preparing the next generation adequately in the knowledge, skills, and competencies required (e.g., Brundiers et al., 2021). Given all these factors, a growing chorus of voices has questioned academia's capability to provide intellectual leadership at all for the sustainability transition. An entire field has emerged - sustainability science - aimed at maintaining the usefulness of science to solving real-world problems (e.g., Polk, 2014; Mooney, 2016; Clark and Harley, 2020; Rocha et al., 2020; Kliskey et al., 2021).

\section{The Reforming University}

Higher education has not remained untouched and unchanged by these critiques, but has self-examined and launched many efforts to rectify and reform problematic aspects of its inner workings and external impact (e.g., Corcoran and Wals, 2004). Many have contributed to the reflection on the future of higher education (formalized through organizations such as $\mathrm{AASHE}^{3}$, fields like "transformative education and learning ${ }^{4}$," international research projects [e.g., INTREPID (Bina et al., 2019); Global Educational Futures (Luksha et al., 2018)], and global efforts through UNESCO ${ }^{5}$. Many universities and professional organizations have made serious efforts at lowering their own contributions to emissions, waste, and environmental toxins through initiatives such as Second Nature ${ }^{6}$ and the UNlead Green University Networks ${ }^{7}$. Similarly, many have reviewed, changed, and refreshed curricula, and promoted more engaging forms of pedagogy (a more learning- and learner-centered approach) (de la Harpe and Thomas, 2009; Barth, 2016; Gaard et al., 2017; Pietrzak et al., 2018; Bina and Pereira, 2020; Bonini, 2020; Stanford University Design School, 2021).

These efforts have led to attempts of defining competencies needed for sustainability (e.g., Fadel et al., 2015; UNESCO, 2017; Rieckmann, 2018; Guimarães et al., 2019). Recognizing the importance of sustainability, various institutions of higher learning have reorganized and coalesced its departments and intellectual contributions into sustainability-focused institutes, initiatives, and centers (for selected examples, see McMillin and

\footnotetext{
${ }^{2}$ See also the fossil fuel divestment campaigns at colleges and universities: https://campaigns.gofossilfree.org/efforts/fossil-fuel-divestment-collegesuniversities [accessed 1-29-21].

${ }^{3}$ See: https://www.aashe.org/ [accessed 1-29-21].

${ }^{4}$ See, for example, journals such as https://journals.sagepub.com/home/jtd, https://jotl.uco.edu/index.php/jotl/about, and https://www.emerald.com/insight/ publication/issn/1467-6370.

${ }^{5}$ See: https://en.unesco.org/themes/education-sustainable-development [accessed 1-29-21].

${ }^{6}$ See: https://secondnature.org/ [accessed 1-29-21].

${ }^{7}$ See: https://www.unenvironment.org/explore-topics/education-environment/wh $\mathrm{y}$-does-education-and-environment-matter/green-university [accessed 1-29-21].
} 
Dyball, 2009). Some also created fairer access and opportunities to minorities and people of lesser privilege (e.g., Klein, 2009; Walsh et al., 2020). Less successfully, albeit while advancing change slowly in the right direction, some universities and research institutions have supported their faculty, staff, and students in working toward greater transdisciplinary engagement with the world of practice and policy (Palma and Pedrozo, 2019; Fazey et al., 2020; Fazey et al., this issue).

\section{The Non-conformist University}

And still, for some these changes have not gone far enough. Nearly 50 years after the very first Rio conference, and through successive decadal summits and IPCC cycles of assessments, academia's verbal commitment to sustainability has been found to be widespread. Yet, the implementation of commensurate changes has at best been irregular and inconsistent, leading some to conclude that higher education is still more part of the problem than of the solution (e.g., Tilbury, 2011). The warning cries of society's unsustainable behavior and inadequate policy response have only grown louder. For example, in January 2021, 17 ecologists issued one of these, in what is the equivalent of scientists shouting:

\begin{abstract}
"The scale of the threats to the biosphere and all its lifeformsincluding humanity-is in fact so great that it is difficult to grasp for even well-informed experts. ... this dire situation places an extraordinary responsibility on scientists to speak out candidly and accurately when engaging with government, business, and the public. We especially draw attention to the lack of appreciation of the enormous challenges to creating a sustainable future. The added stresses to human health, wealth, and well-being will perversely diminish our political capacity to mitigate the erosion of ecosystem services on which society depends." (Bradshaw et al., 2021, p. 1)
\end{abstract}

While it is clearly not only academia's responsibility to address this breathtaking shortfall in leadership and action, academia does have a prominent role in preparing the current and next generation of leaders who must take up that mantle. Not surprisingly, there remains a persistent critique - from within and without - of the neoliberal commitments of universities in the (re)production of knowledge, of reductionist ways of thinking, and production of conformist consumers (e.g., Olssen and Peters, 2005; Saunders, 2010; Olssen, 2016; Busch, 2017; Connell, 2019). Sharp critiques have thus been leveraged against the complicit outcomes of teaching and research, followed by growing calls for subversive and transgressive learning (e.g., LotzSisitka et al., 2015; Macintyre et al., 2018; Selby and Kagawa, 2018). Despite a long-standing acknowledgment of the need to give students more agency in their own education, few universities have gone far beyond giving lip service to this ideal (e.g., Astin, 1999/1984; Manning et al., 2013) ${ }^{8}$. Many continue to argue that the impact of sustainability education and research does not go far enough, has too little impact, likely because it does not address the most consequential leverage points, i.e., the

\footnotetext{
${ }^{8} \mathrm{~A}$ bright example is the student-led office, called Student Organizations, Media, and Culture and Arts or SOMeCA, at the University of California-Santa Cruz; see: http://studentswithagency.ucsc.edu/ [accessed 1/30/21].
}

deepest drivers of societal behavior, namely its worldviews, belief systems, paradigms, and values (e.g., Burns, 2012; O'Brien, 2013, 2016; O’Brien et al., 2013; O’Brien and Selboe, 2015; Bai et al., 2016; Abson et al., 2017; Albrecht, 2020).

This has led some to shift the emphasis in education, as noted by Burns (2018):

\begin{abstract}
"The field of sustainability education has been largely focused on learning that promotes sustainable change, both individual and systemic, seeking solutions for our destructive and divisive societies that are ecologically resilient, socially just, and economically viable and localized. As this field has developed, educators have also recognized the need for the integration of learning that can more deeply transform our unsustainable ways of being and knowing" (p. 277).
\end{abstract}

Clearly, critics have called out the limits of instrumentalist approaches to education and instead pushed educators to better account for the inner dimension of learning and growth in transformative (sustainability) education (de Witt et al., 2014; Horlings, 2015; de Witt, 2016; Woiwode, 2016, 2020; Burns, 2018; Parodi and Tamm, 2018; Scharmer, 2018; Wamsler and Brink, 2018; Wamsler et al., 2018; Brendel and CornettMurtada, 2019; Grenni et al., 2020; Ives et al., 2020; Pisters et al., 2020). Across the board, these much-needed voices call for more engaged, empowering, and creative pedagogies, and the uptake of skills and practices among learners required to grasp and deal with the "dire situation" humanity faces. Typical recommendations include the uptake of practices that foster mindfulness, reflexivity, self-awareness, a redirection from individualistic and materialist values toward cooperative and common-good values, as well as an active grappling with the emotional experience of living through the climate and ecocidal crisis of our time (e.g., Pihkala, 2020; Sherman, 2021).

\section{CONCEIVING THE UNIVERSITY OF THE FUTURE \\ The Necessary Reframing of a University's Purpose}

Stepping back from these specific critiques and responses of the modern(ist) University, we would argue, the incremental reforms and even more radical changes proposed are critical and necessary, but do not yet go far enough to match the challenges before us. While pushing for structural and behavioral changes to lessen universities' negative ecological impact, they maintain, even as they extend, the notion of universities as centers of scientific exploration and excellence and (secondarily) as places of human education. This does not go far enough. While we see the "non-conformist" efforts described above as most promising in their value commitments and aim at the kind of empowerment and emancipation needed, we wish to propose a more radical reframing of the necessary ambition.

For this purpose, we draw on depth psychology and work on initiation, particularly the work of eco-depth psychologist and 
wilderness-based soul initiation guide, Bill Plotkin ${ }^{9}$, and other kin contributors to personal and cultural transformation, albeit relying on different models of the maturation process (e.g., van Gennep, 2004/1960; Berry, 2015/1988, 1990; Mahdi et al., 1998; Henderson, 2005; Weller, 2015; Shaw, 2016; Hollis, 2020).

Universities are one potentially important place - albeit not the only one - to initiate the next generation into becoming the adult humans needed to navigate the difficult future of the Anthropocene (Berzonsky and Moser, 2017). The depth and extent of transformation that awaits society and that is needed to arrive - in time - at a sustainable, not human-dominated Earth requires developmentally mature, and in fact, initiated adults (Plotkin, 2008, 2021).

The University of the future is likely to fail this mission, if it "only" prepares young people in the kinds of knowledge and technical expertise required to manage accelerating climate crises and the breakdown of Earth's life support and interlocking human systems (Maxwell, 2007; Fazey et al., 2020). It will likewise fall short, if it builds some of the psychological and social skills and competencies needed but does not recognize and place them within an understanding of the developmental needs of individuals and societies on their paths coming into mature adulthood. In this essential process for human maturation, individuals - according to Plotkin - go through a multi-staged process - "the descent to soul, [in which they experience] the dissolution of current identity; the encounter with the mythopoetic mysteries of soul; and the metamorphosis of the ego into a cocreator of life-enhancing culture" (Plotkin, 2021). Instead, the University of the future must become a crucial hub for human (psychological) development.

\section{The Educational Horizon: Mature, Eco-Centric Humans}

The University of the future that we envision must take on - and embody itself - an eco-psychologically transformative mission from which mature, eco-, and soul-centric humans emerge, ready to commit to enacting their deepest purpose not just in their own lives or in society but in the larger Earth community (Plotkin, 2021). This will change the University from being primarily a place of technical, vocational, and intellectual advancement to a place - in the first instance - of societal reckoning, of grieving, and actively shedding and dismantling the modernist ways that have brought on the multi-pronged eco-social crisis we now face. As such, it must become a place where psychological adolescents (of all ages) stop conforming to and perpetuating a destructive, individualistic, narcissistic, materialist, competitive, growth-oriented culture. Instead, it must become a safe but demanding space for exploring one's true place, one's "ecological niche" or soul (Plotkin, 2021) in the larger Earth community; where people work to find and begin to embody their unique contributions to a socially and ecologically regenerative, restorative culture.

As Astin and Astin (2000) stated,

\footnotetext{
${ }^{9}$ For further background on Plotkin's work, see: https://www.animas.org/aboutus/our-founder/.
}

To cope effectively and creatively with these emerging national and world trends [of social and environmental disruption and decay], future leaders will not only need to possess new knowledge and skills, but will also be called upon to display a high level of emotional and spiritual wisdom and maturity (p. 1).

This call for a "high level of emotional and spiritual wisdom and maturity" points not just to knowledge absorption and skillbuilding but to a psychological transformation that is necessary to generate the kinds of change agents/leaders that society needs to restore the conditions for survival and thriving, justice, peaceful coexistence, reciprocal care, dignity, and ecological healing (Astin and Astin, 2000, p. 8-16; Plotkin, 2021).

Understanding the psychological "ordeal" involved in healing from the personal and collective traumas we all carry, restoring one's own wholeness (Plotkin, 2013; Hübl and Avritt, 2020), and readying for and undergoing the arduous search for one's deepest niche in life (not merely a lucrative career or livelihood), thus points to more than institutional and curricular reform (although they are still required). It points to the need for creating and holding a space for an innate, but in modern societies perilously stifled process, by which humans come to learn of their "gift" to the larger human and Earth community, an offering that is essential for the thriving and continuation of those communities.

While many observers point to some of the skills and characteristics of authentic adults (Astin, 1992; Astin and Astin, 2000; Freire, 2008; Wiek et al., 2011; Roczen et al., 2014; Fadel et al., 2015; UNESCO, 2017; Bruce et al., 2018; Rieckmann, 2018; Levesque and Tichenor Blackstone, 2020; Brundiers et al., 2021; Redman et al., 2021), harboring back to the ideals of liberal and emancipatory education, they do not typically recognize them as the outcome of a crucial psychological transformative process. Consequently, they bemoan and make impassioned pleas against, the pressures of delivering on institutional values and incentives that undermine the achievement of these goals, but they do not recognize the need for creating the psycho-social container for the process of maturation.

Doing so - as guides and mentors - would mean giving space for our own and students' learning and transformation from who we are to what we all could be. It would mean facing our demons and fears head on, unlearning as much as we learn. It would mean breaking the chains of social conditioning and "learning others," and instead developing the capacity to hold spaces for oneself and others to undergo and trust in one's/their own transformation. It would mean equipping those involved in the midst of such change with appropriate practices and tasks to deepen into their quest, and in the process building dispositions for deeper seeking, reflection, personal change, and motivations for lifelong learning, curiosity in, accepting the hardships of, and thriving amidst change. It would mean building agency on behalf of one's highest self rather than one's individualistic desires, while instilling a desire for inward experiencing and outward restoration. And as this involves the depth and breadth of human emotional and spiritual experiences, it would involve building significant skills in "being with" one's inner world and how it responds and engages with the outer world. It would mean building the psychological stamina for hardship and embracing the inevitable, 
a kind of fearlessness and boldness coupled with awareness and humility in the face of our own frailties and inadequacies.

Skilled guides and mentors would understand the arc of this monumental developmental shift and not impose their own interpretation on the process, but mirror a mentee's journey back to them. It is up to each person to discover what their unique "niche" and "gift" are. Others can only be respectful, curious, and ideally skilled facilitators of a process that leads to an innermost, sacred discovery. From this discovery, individuals will need to build the skills to enact these gifts in service to the larger Earth community, and in this way offer their soul-centered, but other-oriented contribution to the healing of the world (Plotkin, 2021). Accompanying others in the process of reaching true adulthood means helping them develop the requisite capacities to navigate, reflect on, and thus become capable of facilitating and helping yet others in their own personal transformation. In this way, the number of mature adults - with a life-sustaining value orientation and capable of navigating, aiding, and supporting the challenging transformation to sustainability - grows. Such a maturation process would go far beyond simply knowledge acquisition or development of competencies and, instead, would aim at the highest leverage points of system change (paradigm and value shifts) and thus contribute to the deep change toward sustainability required. To create the conditions for such a shift in self-understanding of the University of the future, engagement, deep reckoning, and action is required across all levels including from faculty, students, staff, senior leaders, and those setting the scene and who have influence in education much more widely.

\section{CONCLUSION}

In this paper we have reviewed widespread critiques of the modern University and its contribution to human education. We agree with the critiques, but have argued that the reformist and non-conformist critiques don't go far enough. Instead, we suggest that universities themselves must transform into institutions that cease to participate, pardon, and propagate patterns of competitiveness and exploitation and, instead, become singularly dedicated to restoring and regenerating the conditions for life in all its meanings. This changes them from institutions of human education to spaces for human development.

\section{REFERENCES}

Abson, D. J., Fischer, J., Leventon, J., Newig, J., Schomerus, T., Vilsmaier, U., et al. (2017). Leverage points for sustainability transformation. Ambio 46, 30-39. doi: 10.1007/s13280-016-0800-y

Albrecht, G. A. (2020). Negating solastalgia: an emotional revolution from the Anthropocene to the Symbiocene. Am. Imago 77, 9-30. doi: 10.1353/aim.2020.0001

Astin, A. W. (1992). The unrealized potential of american higher education. Innov. High. Educ. 17, 95-114. doi: 10.1007/BF00 917132

Astin, A. W. (1999/1984). Student involvement: a developmental theory for higher education. J. Coll. Stud. Devel. 40, 518-529.

Astin, A. W., and Astin, H. S. (2000). Leadership Reconsidered: Engaging Higher Education in Social Change. Battle Creek, MI: W.K. Kellogg Foundation.
Our goal was to put forward a vision of the future University, not to engage - at this point - in questions of implementation. A focus on implementation would need to lay out more fully how current approaches to equipping young people for life would need to change; the roles played by different University actors in supporting the maturation process; and addressing both developmental, institutional, cultural, and funding barriers. For now, in this paper, we set out with proposing a sharp reframing of the purpose of the University, one that is cognizant of the existential threat humanity now faces, and that therefore urgently reorients from contributing to the destructive drivers of society to contributing to the restoration of the conditions for life. As Astin (1992) argued nearly 30 years ago,

\begin{abstract}
"It is time ... to begin concerning ourselves much more directly with the development of values and beliefs that are going to heal our divisions, and which will help to create a society that is less materialistic, fearful, and competitive, and more generous, trusting, and cooperative" (p. 114).
\end{abstract}

It is far later now, but not too late. If humans are to have a prayer at survival at all, such a radical turn toward saving and restoring the conditions for life is necessary now. Universities must reckon whether it is life they want. Another day. A role and task on Earth worthy of their name.

\section{DATA AVAILABILITY STATEMENT}

The original contributions presented in the study are included in the article/supplementary material, further inquiries can be directed to the corresponding author.

\section{AUTHOR CONTRIBUTIONS}

SM and IF have been in a long-standing conversation about the need for a radically different vision of the University. Both authors engaged in an embodied practice to vision a more fitting place of higher learning. This led to the underlying ideas for the paper. SM took the lead in drafting the paper and IF offered comments, ideas, and edits. All authors contributed to the article and approved the submitted version.

Bai, X., van der Leeuw, S., O’Brien, K., Berkhout, F., Biermann, F., Brondizio, E. S., et al. (2016). Plausible and desirable futures in the Anthropocene: a new research agenda. Global Environ. Change 39, 351-362. doi: 10.1016/j.gloenvcha.2015.09.017

Barth, M. (2016). Implementing Sustainability in Higher Education Learning in an Age of Transformation. London: Routledge.

Berman, E. P. (2014). Not just neoliberalism: economization in us science and technology policy. Sci. Technol. Human Values 39, 397-431. doi: $10.1177 / 0162243913509123$

Berry, T. (1990). The Great Work: Our Way Into the Future. New York, NY: Bell Tower.

Berry, T. (2015/1988). The Dream of the Earth. Berkeley, CA: Counterpoint.

Berzonsky, C. L., and Moser, S. C. (2017). Becoming homo sapiens sapiens: mapping the psycho-cultural transformation in the Anthropocene. Anthropocene 20, 15-23. doi: 10.1016/j.ancene.2017.11.002 
Bina, O., and Pereira, L. (2020). Transforming the role of universities: from being part of the problem to becoming part of the solution. Environment 62, 16-29. doi: 10.1080/00139157.2020.1764286

Bina, O., Varanda, M., and Guevara, M. (2019). INTREPID: Knowledge: Interdisciplinary and Transdisciplinary Research and Collaboration. Lisbon: INTREPID, University of Lisbon.

Bonini, P. (2020). When tomorrow comes: technology and the future of sustainability learning in higher education. Environment 62, 39-48. doi: 10.1080/00139157.2020.1764300

Bradshaw, C. J. A., Ehrlich, P. R., Beattie, A., Ceballos, G., Crist, E., Diamond, J., et al. (2021). Underestimating the challenges of avoiding a ghastly future. Front. Conserv. Sci. 1:615419. doi: 10.3389/fcosc.2020.615419

Brendel, W., and Cornett-Murtada, V. (2019). Professors practicing mindfulness: an action research study on transformed teaching, research, and service. J. Transform. Educ. 17, 4-23. doi: 10.1177/1541344618762535

Bruce, H. R., David, R., and Michael, M. (2018). Wicked leadership competencies for sustainability professionals: definition, pedagogy, and assessment. Sustainability 11, 171-177. doi: 10.1089/sus.2018.0008

Brundiers, K., Barth, M., Cebrián, G., Cohen, M., Diaz, L., Doucette-Remington, S., et al. (2021). Key competencies in sustainability in higher educationtoward an agreed-upon reference framework. Sustain. Sci. 16, 13-29. doi: 10.1007/s11625-020-00838-2

Burke, B. J., and Nik, H. (2014). Transforming participatory science into socioecological praxis: valuing marginalized environmental knowledges in the face of the neoliberalization of nature and science. Environ. Soc. 5, 17-27. doi: $10.3167 /$ ares.2014.050102

Burns, H. (2018). Thematic analysis: transformative sustainability education. J. Transform. Educ. 16, 277-279. doi: 10.1177/1541344618796996

Burns, T. R. (2012). The sustainability revolution: a societal paradigm shift. Sustainability 4, 1118-1134. doi: 10.3390/su4061118

Busch, L. (2017). Knowledge for Sale: The Neoliberal Takeover of Higher Education. Cambridge, MA: MIT Press. doi: 10.7551/mitpress/10742.001.0001

Clark, W. C., and Harley, A. G. (2020). Sustainability science: toward a synthesis. Ann. Rev. Environ. Resour. 45, 331-386. doi: 10.1146/annurev-environ-012420-043621

Connell, R. (2019). The Good University: What Universities Actually Do and Why Its Time for Radical Change. London: Zed Books Ltd. doi: 10.1111/ajph.12605

Corcoran, P. B., and Wals, A. E. J. (eds.). (2004). Higher Education and the Challenge of Sustainability: Problematics, Promise, and Practice. Dordrecht: Kluwer Academic Publishers, Springer. doi: 10.1007/0-306-48515-X

de la Harpe, B., and Thomas, I. (2009). Curriculum change in universities: conditions that facilitate education for sustainable development. J. Educ. Sustain. Dev. 3, 75-85. doi: 10.1177/097340820900300115

de Witt, A. (2016). "Global warming calls for an inner climate change: the transformative power of worldview reflection for sustainability," in Spirituality and Sustainability: New Horizons and Exemplary Approaches, eds S. Dhiman and J. Marques (Cham: Springer International Publishing), 199-214. doi: 10.1007/978-3-319-34235-1_13

de Witt, A. H., Boer, J. d., and Boersema, J. J. (2014). Exploring inner and outer worlds: a quantitative study of worldviews, environmental attitudes, and sustainable lifestyles. J. Environ. Psychol. 37, 40-54. doi: 10.1016/j.jenvp.2013.11.005

Fadel, C., Bialik, M., and Trilling, B. (2015). Four-Dimensional Education: The Competencies Learners Need to Succeed. Boston, MA: Center for Curriculum Redesign.

Fazey, I., Schäpke, N., Caniglia, G., Hodgson, A., Kendrick, I., Lyon, C., et al. (2020). Transforming knowledge systems for life on Earth: visions of future systems and how to get there. Energy Res. Soc. Sci. 70:101724. doi: 10.1016/j.erss.2020.101724

Feuerbach, L. (1893). The Essence of Christianity. London: Kegan Paul, Trench, Truebner and Co. Ltd.

Freire, P. (2008). Pedagogy of the Oppressed. New York, London: Continuum.

Gaard, G. C., Blades, J., and Wright, M. (2017). Assessing sustainability curriculum: from transmissive to transformative approaches. Int. J. Sustain. High. Educ. 18, 1263-1278. doi: 10.1108/IJSHE-11-2015-0186

Grenni, S., Soini, K., and Horlings, L. G. (2020). The inner dimension of sustainability transformation: how sense of place and values can support sustainable place-shaping. Sustain. Sci. 15, 411-422. doi: 10.1007/s11625-019-00743-3

Guimarães, M. H., Pohl, C., Bina, O., and Varanda, M. (2019). Who is doing inter-and transdisciplinary research, and why? An empirical study of motivations, attitudes, skills, and behaviours. Futures 112:102441. doi: 10.1016/j.futures.2019.102441

Henderson, J. L. (2005). Threshold of Initiation. Wilmette, IL: Chiron Publications.

Hollis, J. (2020). Living Between Worlds: Finding Personal Resilience in Changing Times. Boulder, CO: Sounds True.

Horlings, L. G. (2015). The inner dimension of sustainability: personal and cultural values. Curr. Opin. Environ. Sustain. 14, 163-169. doi: 10.1016/j.cosust.2015.06.006

Hübl, T., and Avritt, J. J. (2020). Healing Collective Trauma: A Process for Integrating Our Intergenerational and Cultural Wounds. Boulder, CO: Sounds True.

Ives, C. D., Freeth, R., and Fischer, J. (2020). Inside-out sustainability: the neglect of inner worlds. Ambio 49, 208-217. doi: 10.1007/s13280-019-01187-w

Klein, J. T. (2009). Creating Interdisciplinary Campus Cultures: A Model for Strength and Sustainability. San Francisco, CA: Jossey-Bass.

Kliskey, A., Alessa, L., Griffith, D., Olsen, S., Williams, P., Matsaw, S., et al. (2021). Transforming sustainability science for practice: a social-ecological systems framework for training sustainability professionals. Sustain. Sci. 16, 283-294. doi: 10.1007/s11625-020-00846-2

Lave, R., Mirowski, P., and Randalls, S. (2010). Introduction: STS and neoliberal science. Soc. Stud. Sci. 40, 659-675. doi: 10.1177/0306312710378549

Leal Filho, W., Morgan, E. A., Godoy, E. S., Azeiteiro, U. M., Bacelar-Nicolau, P., Veiga Ávila, L., et al. (2018). Implementing climate change research at universities: barriers, potential and actions. J. Clean. Prod. 170, 269-277. doi: 10.1016/j.jclepro.2017.09.105

Levesque, V. R., and Tichenor Blackstone, N. (2020). Exploring undergraduate attainment of sustainability competencies. Sustainability 13, 32-38. doi: 10.1089/sus.2019.0022

Lotz-Sisitka, H., Wals, A. E. J., Kronlid, D., and McGarry, D. (2015). Transformative, transgressive social learning: rethinking higher education pedagogy in times of systemic global dysfunction. Curr. Opin. Environ. Sustain. 16, 73-80. doi: 10.1016/j.cosust.2015.07.018

Luksha, P., Cubista, J., Laszlo, A., Popovich, M., and Ninenko, I. (2018). Educational Ecosystems for Societal Transformation: Global Education Futures Report. Global Education Futures Report, Global Education Futures Initiative, Aurora, CO, United States.

Macintyre, T., Lotz-Sisitka, H., Wals, A., Vogel, C., and Tassone, V. (2018). Towards transformative social learning on the path to 1.5 degrees. Curr. Opin. Environ. Sustain. 31, 80-87. doi: 10.1016/j.cosust.2017.12.003

Mahdi, L. C., Christopher, N. G., and Meade, M. (eds.). (1998). Crossroads: The Quest for Contemporary Rites of Passage. McLean, VA: Open Court.

Manning, K., Kinzie, J., and Schuh, J. (2013). "Chapter 7: Student-centered innovative models," in One Size Does Not Fit All: Traditional and Innovative Models of Student Affairs Practice, 2nd Edn, eds K. Manning, J. Kinzie, and J. Schuh. (New York, NY: Routledge), 24. doi: 10.4324/9781315885353

Maxwell, N. (2007). From Knowledge to Wisdom: A Revolution for Science and the Humanities. 2nd Edn. London: Pentire Press.

Mayo, N. (2019, September 12). How green is my University? The Times for Higher Education. COMPLETE

McMillin, J., and Dyball, R. (2009). Developing a whole-of-University approach to educating for sustainability: linking curriculum, research and sustainable campus operations. J. Educ. Sustain. Dev. 3, 55-64. doi: 10.1177/097340820900300113

Moon Christopher, J., Walmsley, A., and Apostolopoulos, N. (2018). Governance implications of the UN higher education sustainability initiative. Corporate Govern. 18, 624-634. doi: 10.1108/CG-01-2018-0020

Mooney, H. (2016). Editorial overview: sustainability science: socialenvironmental systems (SES) research: how the field has developed and what we have learned for future efforts. Curr. Opin. Environ. Sustain. 19, v-xii. doi: 10.1016/j.cosust.2016.05.002

O'Brien, K. (2013). Global environmental change III: closing the gap between knowledge and action. Prog. Hum. Geogr. 37, 587-596. doi: $10.1177 / 0309132512469589$ 
O’Brien, K., Reams, J., Caspari, A., Dugmore, A., Faghihimani, M., Fazey, I., et al. (2013). You say you want a revolution? Transforming education and capacity building in response to global change. Environ. Sci. Policy 28, 48-59. doi: 10.1016/j.envsci.2012.11.011

O'Brien, K., and Selboe, E. (2015). "Social transformation: the real adaptive challenge," in The Adaptive Challenge of Climate Change, eds K. O'Brien and E. Selboe (New York, NY: Cambridge University Press), 311-324. doi: 10.1017/CBO9781139149389.018

O'Brien, K. L. (2016). Climate change and social transformations: is it time for a quantum leap? Wiley Interdiscip. Rev. 7, 618-626. doi: 10.1002/wcc.413

Olssen, M. (2016). Neoliberal competition in higher education today: research, accountability and impact. Br. J. Sociol. Educ. 37, 129-148. doi: 10.1080/01425692.2015.1100530

Olssen, M., and Peters, M. A. (2005). Neoliberalism, higher education and the knowledge economy: from the free market to knowledge capitalism. J. Educ. Policy 20, 313-345. doi: 10.1080/02680930500108718

O'Riordan, T., Jacobs, G., Ramanathan, J., and Bina, O. (2020). Investigating the future role of higher education in creating sustainability transitions. Environment 62, 4-15. doi: 10.1080/00139157.2020.1764278

Palma, L. C., and Pedrozo, E. Á. (2019). Transformation for sustainability and its promoting elements in educational institutions: a case study in an institution focused on transformative learning. Organizações Sociedade 26, 359-382. doi: $10.1590 / 1984-9260898$

Parodi, O., and Tamm, K. (2018). Personal Sustainability: Exploring the Far Side of Sustainable Development. London: Routledge. doi: 10.4324/9781315159997

Pietrzak, B., Ward, A., Cheung, M. K., Schwendimann, B. A., Mollaoglu, G., Duong, M. T., et al. (2018). Education for the future. Science 360, 1409-1412. doi: $10.1126 /$ science.aau3877

Pihkala, P. (2020). Eco-anxiety and environmental education. Sustainability 12:10149. doi: 10.3390/su122310149

Pisters, S. R., Vihinen, H., and Figueiredo, E. (2020). Inner change and sustainability initiatives: exploring the narratives from eco-villagers through a place-based transformative learning approach. Sustain. Sci. 15, 395-409. doi: $10.1007 / \mathrm{s} 11625-019-00775-9$

Plotkin, B. (2008). Nature and the Human Soul: Cultivating Wholeness and Community in a Fragmented World. Novato, CA: New World Library.

Plotkin, B. (2013). Wild Mind: A Field Guide to the Human Pscyhe. Novato, CA: New World Library.

Plotkin, B. (2021). The Journey of Soul Initiation: A Field Guide for Visionaries, Evolutionaries, and Evolutionaries +. Novato, CA: New World Library.

Polk, M. (2014). Achieving the promise of transdisciplinarity: a critical exploration of the relationship between transdisciplinary research and societal problem solving. Sustain. Sci. 9, 439-451. doi: 10.1007/s11625-014-0247-7

Redman, A., Wiek, A., and Barth, M. (2021). Current practice of assessing students' sustainability competencies: a review of tools. Sustain. Sci. 16, 117-135. doi: 10.1007/s11625-020-00855-1

Rieckmann, M. (2018). "Learning to transform the world: Key competencies in education for sustainable development," in Issues and Trends in Education for Sustainable Development, eds A. Leicht, J. Heiss, and W. Byun (Paris: UNESCO Publishing), 39-59.

Rocha, P. L. B. d., Pardini, R., Viana, B. F., and El-Hani, C. N. (2020). Fostering inter- and transdisciplinarity in discipline-oriented universities to improve sustainability science and practice. Sustain. Sci. 15, 717-728. doi: 10.1007/s11625-019-00761-1

Roczen, N., Kaiser, F. G., Bogner, F. X., and Wilson, M. (2014). A competence model for environmental education. Environ. Behav. 46, 972-992. doi: $10.1177 / 0013916513492416$

Saunders, D. B. (2010). Neoliberal ideology and public higher education in the United States. J. Critic. Educ. Policy Stud. 8, 41-77. Available online at: http:// www.jceps.com/archives/626 (accessed January 29, 2021).

Scharmer, O. (2018, 8 January). Education is the kindling of a flame: how to reinvent the 21st-century University. Huffpost. Available online at: https:// www.huffpost.com/entry/education-is- the-kindling- of-a-flame-how-toreinvent_b_5a4ffec5e4b0ee59d41c0a9f (accessed January 29, 2021).

Selby, D., and Kagawa, F. (2018). Teetering on the brink:Subversive and restorative learning in times of climate turmoil and disaster. J. Transform. Educ. 16, 302-322. doi: 10.1177/1541344618 782441

Shaw, M. (2016). Scatterlings: Getting Claimed in the Age of Amnesia. Ashland, OR: White Cloud Press.

Sherman, G. L. (2021). Transformative lLearning and well-being for emerging adults in higher education. J. Transform. Educ. 19, 29-49. doi: $10.1177 / 1541344620935623$

Stanford University Design School (2021). Uncharted Territory: A Guide to Reimagining Higher Education. Stanford, CA: Stanford University, Hasso Plattner Institute of Design. Available online at: https://dschool.stanford.edu/ unchartedterritory (accessed January 29, 2021).

Tilbury, D. (2011). "Higher education for sustainability: a global overview of commitment and progress," in Higher Education's Commitment to Sustainability: From Understanding to Action, ed J. Granados Sanchez (Barcelona: Global University Network for Innovation), 1-21.

UNESCO (2017). Education for Sustainable Development Goals: Learning Objectives. Paris: United Nations Educational, Scientific and Cultural Organization.

van Gennep, A. (2004/1960). The Rites of Passage. London, New York: Routledge. doi: 10.7208/chicago/9780226027180.001.0001

Walsh, Z., Böhme, J., Lavelle, B. D., and Wamsler, C. (2020). Transformative education: towards a relational, justice-oriented approach to sustainability. Int. J. Sustain. High. Educ. 21, 1587-1606. doi: 10.1108/IJSHE-05-2020-0176

Wamsler, C., and Brink, E. (2018). Mindsets for sustainability: exploring the link between mindfulness and sustainable climate adaptation. Ecol. Econ. 151, 55-61. doi: 10.1016/j.ecolecon.2018.04.029

Wamsler, C., Brossmann, J., Hendersson, H., Kristjansdottir, R., McDonald, C., and Scarampi, P. (2018). Mindfulness in sustainability science, practice, and teaching. Sustain. Sci. 13, 143-162. doi: 10.1007/s11625-017-0428-2

Weller, F. (2015). The Wild Edge of Sorrow: Rituals of Renewal and the Sacred Work of Grief. Berkeley, CA: North Atlantic Books.

Wiek, A., Withycombe, L., and Redman, C. L. (2011). Key competencies in sustainability: a reference framework for academic program development. Sustain. Sci. 6, 203-218. doi: 10.1007/s11625-011-0132-6

Woiwode, C. (2016). Off the beaten tracks: the neglected significance of interiority for sustainable urban development. Futures 84, 82-97. doi: 10.1016/j.futures.2016.10.002

Woiwode, C. (2020). Inner transformation for 21st-century futures: the missing dimension in higher education. Environment 62, 30-38. doi: 10.1080/00139157.2020.1764299

Yañez, P., Sinha, A., and Vásquez, M. (2020). Carbon footprint estimation in a University campus: evaluation and insights. Sustainability 12:181. doi: $10.3390 /$ su12010181

Conflict of Interest: SM is the Director of Susanne Moser Research \& Consulting, an independent research firm. No commercial interest or gain was involved in writing this article.

The remaining author declares that the research was conducted in the absence of any commercial or financial relationships that could be construed as a potential conflict of interest.

Copyright (c) 2021 Moser and Fazey. This is an open-access article distributed under the terms of the Creative Commons Attribution License (CC BY). The use, distribution or reproduction in other forums is permitted, provided the original author(s) and the copyright owner(s) are credited and that the original publication in this journal is cited, in accordance with accepted academic practice. No use distribution or reproduction is permitted which does not comply with these terms. 